\title{
"Debemos escuchar a las mamitas"
}

\author{
Listen to mom
}

Trillada frase que los pediatras repiten incansablemente a los estudiantes de la pediatría. Veamos un ejemplo.

Una niña, de procedencia peruana y 2 años de edad, fue traída a nuestro Servicio de Urgencia su madre. Motivo: fiebre y deposiciones con sangre. Fecha de ocurrencia: marzo 2007.

La madre, angustiada, apenas entró en la sala de atención, la dijo espontáneamente al pediatra de turno: "Dr. creo que mi hija tiene un síndrome hemolitico urémico (SHU). Vengo de Argentina donde el SHU es muy común, yo se qué enfermedad es esa y mi hija no está orinando desde anoche".

Ante tal presentación, el médico procedió a internar la niña, pese a que no se veía comprometida, e indicó su manejo sintomático (dieta ad-hoc, hidratación). Los exámenes de hemograma, orina y función renal fueron normales. Al cabo de 48 horas de observación, la niña se fue de alta, habiendo recuperado su hidratación y estando con buen tránsito intestinal.

Tras su egreso se recibió el informe de un coprocultivo (+) para Escherichia coli 0157.

Vanos fueron los intentos por ubicar a la madre y a su hija en el domicilio de sus parientes. Imposible: ya habían regresado a Bs Aires. ¿Cuál habría sido su evolución post alta?

Diez días más tarde, cuando este episodio había sido olvidado, la microbióloga de nuestro hospital recibió un afligido llamado telefónico desde Bs. Aires: era la madre que solicitaba se le enviara el informe del coprocultivo, sabía por sus parientes que algo se había encontrado en las deposicio-

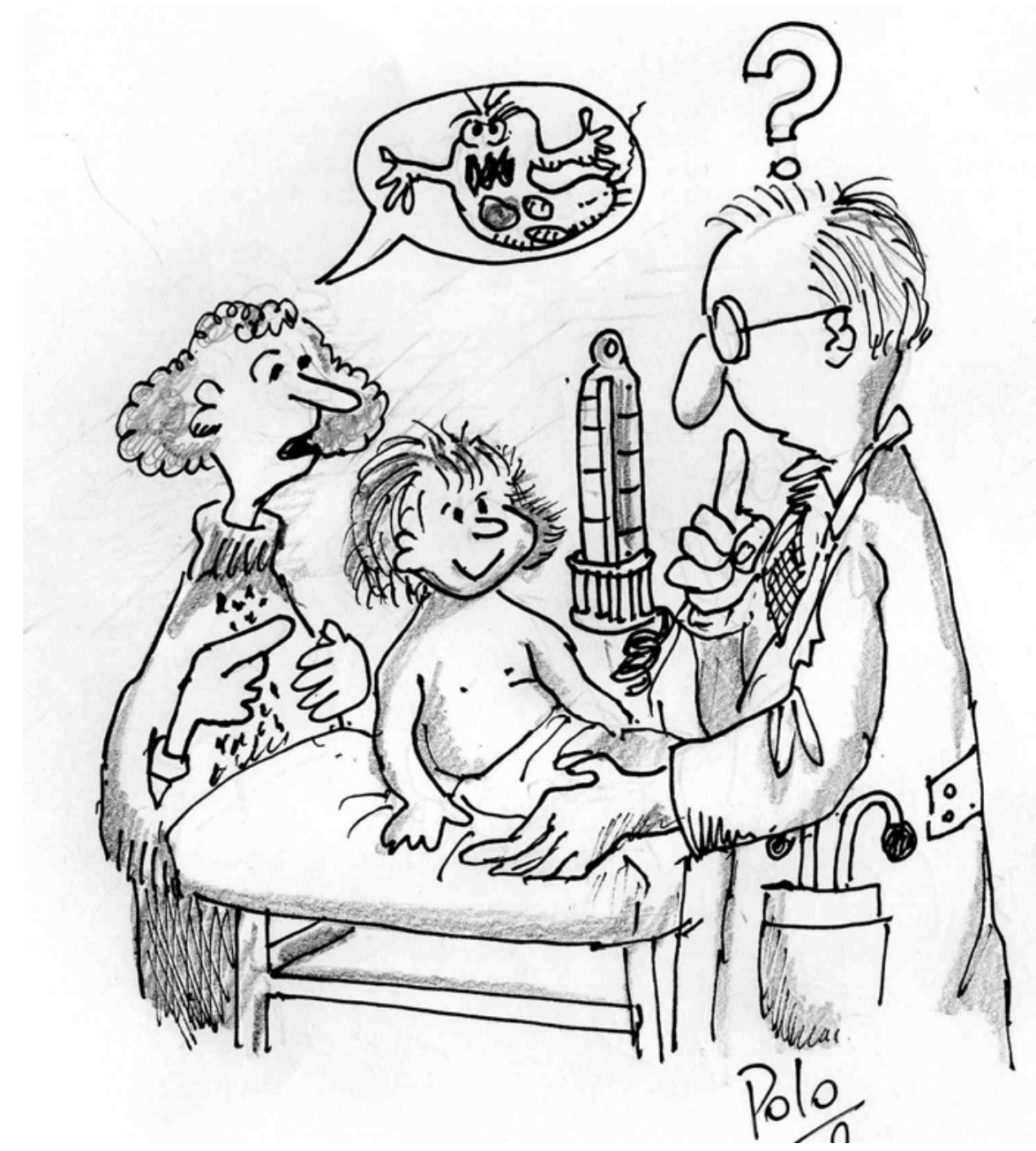

nes de la paciente y ahora... isu hija estaba internada en un hospital de esa ciudad por un SHU! Los médicos allá no habían detectado el microbio que ella decía tener la niña.

Comentario: ¡Qué llamativo el alerta de esta modesta madre, quien vive en un país que ha educado a su población sobre los riesgos de consumir carne contaminada y sobre la asociación de deposiciones sanguinolentas con riesgo de SHU! 